\title{
Intracellular Control of Renin Release - An Overview
}

\author{
A. Kurtz \\ Physiologisches Institut der Universität Zürich
}

The renin angiotensin aldosterone system is an important regulator of the extracellular volume and of the control of blood pressure. It is mainly controlled in its activity by the rate of renin release from the kidney. Within the kidney renin is produced, stored and released from the so-called granular juxtaglomerular cells. These cells are modified smooth muscle cells and are found in the tunica media of the afferent arteriole, just adjacent to the glomerulus. They resemble morphologically vascular smooth muscle cells but have also characteristic features of secretory cells with respect to a welldeveloped endoplasmic reticulum, a prominent Golgi-apparatus and membrane bound granules containing renin $[6,73]$.

Since the rate of renin release from juxtaglomerular cells has a direct effect on blood pressure and because an enhanced rate of renin release is known to be a major reason of hypertension, the mechanisms controlling renal renin release have attracted considerable interest among physiologists, pharmacologists and clinicians.

So far four basic mechanisms controlling renin release from the kidney have been described [26]. These comprise

1. The intra-renal blood pressure, which influences renin release by an as yet undefined baroreceptor.

2. The amount of NaCl-load sensed by the macula densa segment of the distal tubule (macula densa sensor).

3. The sympathetic nervous system

4. A large number of humoral factors like catecholamines, angiotensin II, vasopressin, atrial natriuretic peptide as well as metabolites as for example adenosine.

In spite of the large body of findings about the modulation and alteration of renal renin release, the intracellular mechanisms by which renin release is controlled within the juxtaglomerular cells are not clearly understood.
During the last years the mechanisms of physiological and pharmacological alterations of renin release have been reviewed $[26,36,39]$. The present contribution wants to concentrate on the intracellular processes that influence renin release from juxtaglomerular cells. The available information will be discussed in front of the background of the present knowledge about the general mechanisms of secretion.

For a variety of secretory cells including adrenal medulla and cortex, pituitary, exocrine and endocrine pancreas, neutrophils and platelets it has been found that the secretory process is triggered by the intracellular levels of calcium and cyclic nucleotides and further by the activity of protein kinase $\mathrm{C}[12,33,64,68,70-72]$. I shall therefore discuss in special the role of intracellular calcium, intracellular cyclic AMP and cyclic GMP and protein kinase $\mathrm{C}$ activity in the control of renin release from juxtaglomerular cells. In this context I will also present our own results obtained from studies on the intracellular control of renin release from isolated juxtaglomerular cells.

\section{Role of Calcium in the Intracellular Control of Renin Release}

The typical secretory process in a large number of secreting cells has been found to be biphasic. The secretory process in these cells is initiated by a high and short-termed rise in the intracellular calcium concentration. This initiation phase is then followed by a so-called sustained phase of secretion and this phase is considered to be maintained the activity of a protein kinase $C$. The rise in intracellular calcium and in consequence the initiation of secretion is brought about by two mechanisms. First, by an enhancement of the transmembrane calcium influx [42] from the extracellular into the intracellular space and second by the release of calcium from intracellular stores $[41,69]$. In view 
of the importance of calcium for the normal secretory process it is obvious therefore to discuss the role of intracellular calcium in the control of renin release from juxtaglomerular cells.

Experimental evidence obtained from incubations with renal cortical slices and incubations with renal glomeruli clearly indicates that the rate of renin release is inversely related to the extracellular concentration of calcium [28, 30, 37, 40, 43, 81]. Assuming that the intracellular and the extracellular calcium concentration are correlated one would expect therefore that the releasing rate of renin is also inversely related to the intracellular concentration of calcium. However, as Churchill has pointed out [17], the assumption of a direct correlation between the extracellular and the intracellular concentration of calcium is incorrect, and the inverse relationship between renin release and extracellular calcium concentration can only give supportive evidence for the role of calcium in the control of renin release. More information about the role of calcium in the intracellular regulation of renin release can be gained from experiments in which the calcium extrusion from the juxtaglomerular cells is blocked. Calcium extrusion from a cell in general is effected by two processes. First, by a sodium-calcium exchange mechanism [4] and second by an energy dependent calcium ATPase $[4,64]$. The activity of the sodium-calcium exchange is driven by the sodium gradient from the extracellular to the intracellular space [8]. Since the sodium gradient between the extra- and the intracellular space is maintained by the activity of the sodium-potassium ATPase, the function of the sodium-calcium exchange is finally linked to the activity of the sodium-potassium ATPase. In consequence, inhibition of the sodium-potassium ATPase by ouabain blocks the sodium-calcium exchange. Therefore ouabain leads to an accumulation of calcium within the cell and in consequence to a rise in the intracellular calcium concentration. Ouabain has been found to inhibit renin release $[14,29,49,58,59]$ and additional evidence was obtained to show that this inhibition is a calcium dependent process $[14,25,58]$. Inhibition of the calcium ATPase by vanadate also inhibits part of the extrusion of calcium and therefore leads to a rise in the intracellular calcium concentration [56]. Vanadate has also been found to inhibit renin release $[18,47]$. These findings indicate that a rise of the intracellular calcium concentration inhibits the secretory process in the juxtaglomerular cells.

Moreover, it has been found that spontaneous renin release from whole kidneys, kidney slices, glomeruli and isolated juxtaglomerular cells is en-

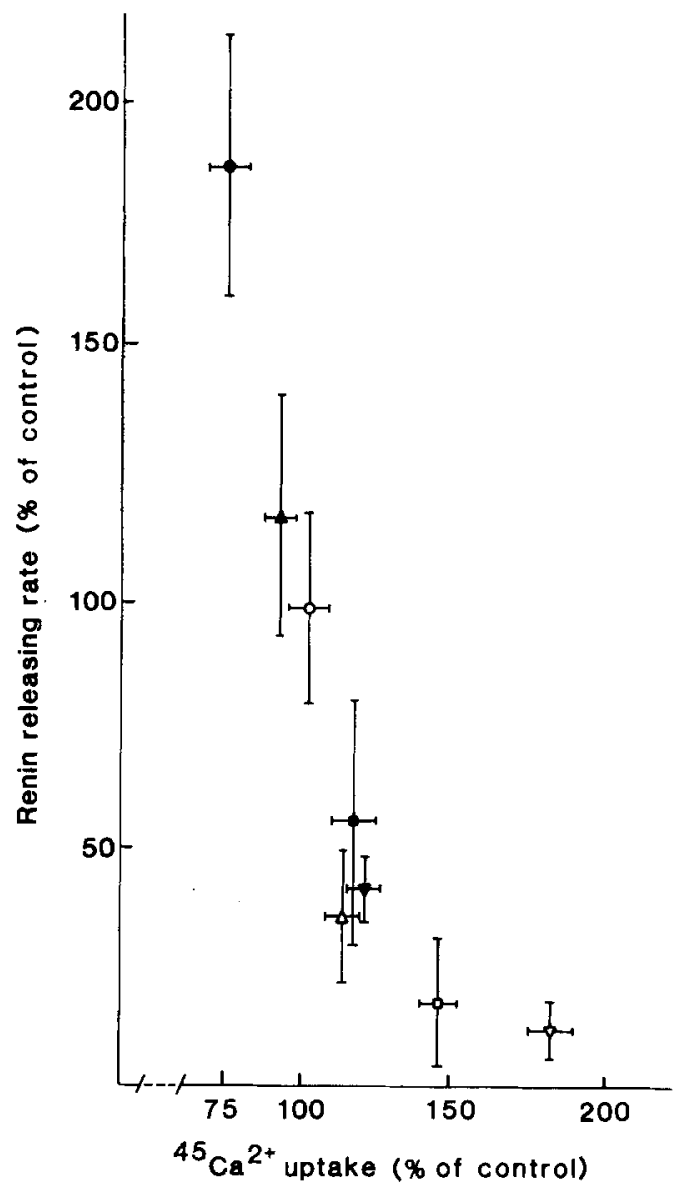

Fig. 1. Correlation between calcium influx into isolated juxtaglomerular cells and rate of renin release from the cells evoked by vasoconstrictors (angiotensin II $\left(10^{-7} \mathrm{M}\right)$, arginine-vasopressin $\left(10^{-6} \mathrm{M}\right)$ and norepinephrine $\left(10^{-5} \mathrm{M}\right)$ in the presence (filled symbols) and absence of verapamil $\left(10^{-5} \mathrm{M}\right.$ ) (open symbols). Data are taken from Ref. 45

hanced by calcium entry blockers [1,24] and inhibited by facilitation of calcium entry $[20,21,27$, 51]. In addition, hormones known to mobilize calcium in several tissues such as angiotensin II, vasopressin and norepinephrine have been found to inhibit renin release by a calcium dependent process $[10,16,77,79]$. Using isolated juxtaglomerular cells, we could show that these hormones enhanced transmembrane calcium influx into the cells and led to a rise in the intracellular calcium concentration [45]. Furthermore we found that that renin release from the juxtaglomerular cells was inversely correlated to the transmembrane calcium influx (Fig. 1). We and others have shown that the inhibitory effect of these agents could be attenuated or even be abolished by calcium channel blockers such as verapamil $[15,45,59]$.

Taken together, all of the findings mentioned above are supportive of the idea that the rate of 
renin release from the juxtaglomerular cells is inversely related to the calcium concentration in the juxtaglomerular cells. In this regard renin secretion behaves strikingly different from the typical mechanism of secretion in which the secretion rate is directly correlated to the intracellular calcium concentration. The mechanism by which intracellular calcium inhibits the secretory process in juxtaglomerular cells is unknown.

Calcium dependent reactions are usually triggered by calcium in two ways, either by the action of ionized calcium or by calcium binding proteins such as calmodulin [13]. Indeed, calcium calmodulin antagonists such as trifluoperazine stimulate renin release from rat glomeruli [38], rat renal cortical slices [22], isolated perfused rat kidneys [31, 65] and isolated juxtaglomerular cells [44]. However, we also found that trifluoperazine inhibited the transmembrane calcium influx into the juxtaglomerular cells, a fact that is also known from other tissues [66]. It is therefore difficult to decide from the experiments using calmodulin antagonists whether or not the inhibitory effect of calcium on renin release is mediated by calmodulin.

\section{Role of Protein Kinase C Activity for the Intracellu- lar Control of Renin Release}

As mentioned above, the secretory process in typical secreting cells is initiated by a rise in the intracellular calcium concentration and is sustained by the activity of the protein kinase $C$. These subsequent intracellular events are usually caused by the activation of a plasma membrane bound phospholipase C (PLC) which splits polyphosphoinositides into inositolphosphates and diacylglycerol [7]. Activators of PLC such as angiotensin II in adrenal glomerulosa cells [64] are therefore typical stimuli for secretion in secretory cells. Protein kinase C (PKC) is normally activated by diacylglycerol [54] and this effect can be mimicked by tumor promoting phorbol esters, such as 12-0-Tetradecanoylphorbol 13-Acetate (TPA) [11]. It is therefore possible to induce a sustained secretory response by the addition of TPA to cells.

We have shown that hormones activating PLC in isolated juxtaglomerular cells such as angiotensin II, arginine-vasopressin, norepinephrine and platelet activating factor strongly inhibit renin release from the cells $[45,61]$. Since activation of PLC causes both calcium mobilisation and activation of PKC and since calcium mobilisation is considered as a strong inhibitory signal for renin release it is difficult to explore the role of PKC for renin release from these experiments. A direct stim-

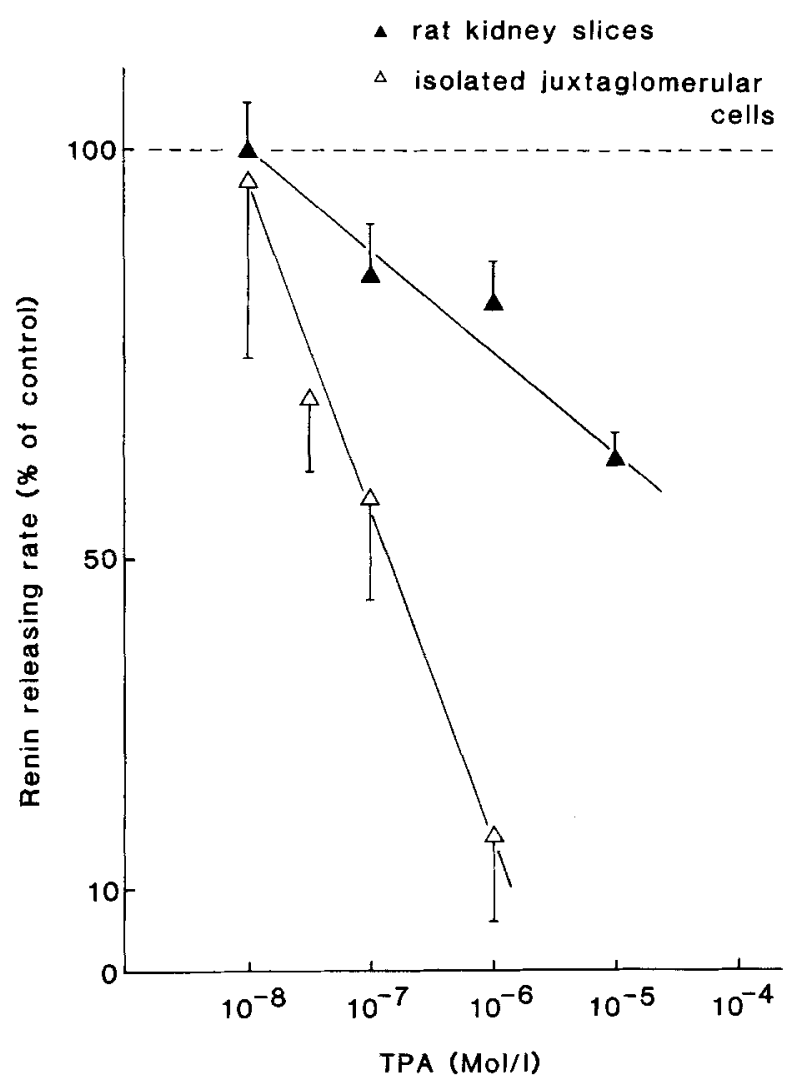

Fig. 2. Effect of 12-O-tetradecanoylphorbol-13-acetate (TPA) on renin relase from rat kidney slices and isolated juxtaglomerular cells. Data are given as percentage of control ( $=$ absence of TPA). Data for renin release from kidney slices were taken from Ref. 23 and that for juxtaglomerular cells from Ref. 45

ulation of PKC activity can be achieved by tumor promoting phorbol esters such as TPA. TPA added either to isolated juxtaglomerular cells [45] or to renal cortical slices [23] leads to a dose-dependent inhibition of renin release from these preparations (Fig. 2). A significant effect of TPA on renin release from both preparations, however, was only observed at rather high concentrations of TPA $\left(10^{-7} \mathrm{M}\right)$. At high concentrations $\left(10^{-6} \mathrm{M}\right)$ TPA is also suspected to act as a calcium ionophore independently of its activating effect on PKC [11]. Since an enhanced calcium influx brought about by a calcium ionophore would be expected to inhibit renin release a direct inhibitory effect of TPA on renin release can therefore not be excluded. Churchill et al., however, reported that the inhibitory effect of TPA on renin release from kidney slices was not due to an ionophore effect [23]. We have found in this context that TPA also enhanced the transmembrane calcium influx into the isolated juxtaglomerular cells [45]. This calcium influx could be blocked by the calcium channel blocker 


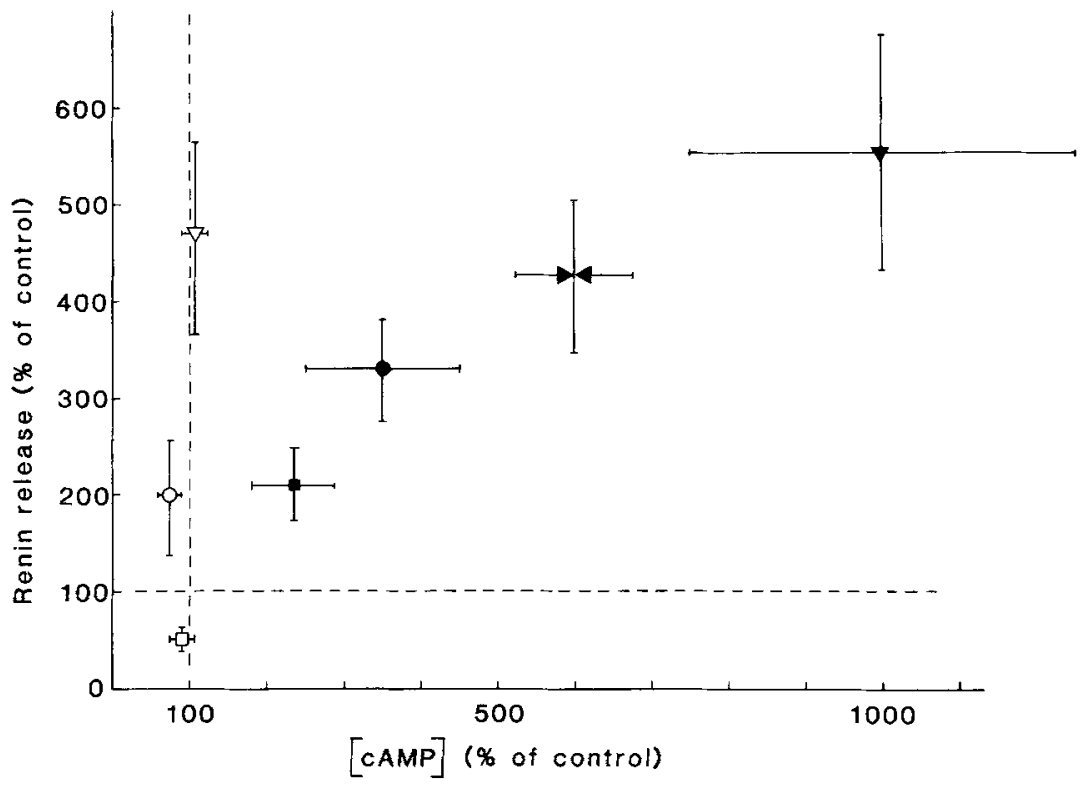

Fig. 3. Correlation between intracellular level of cAMP and renin releasing rate from isolated juxtaglomerular cells. Filled symbols refer to experiments done with activators of adenylate cyclase. $\checkmark$ forskolin $10^{-5} \mathrm{M}$ A prostacycline $10^{-4} \mathrm{M}$ - isoproterenol $10^{-5} \mathrm{M}$

- adenosine $10^{-4} \mathrm{M}$

o verapamil $10^{-5} \mathrm{M}$

$\nabla$ trifluoperazine $10^{-6} \mathrm{M}$

a angiotensin II $10^{-7} \mathrm{M}$

Data are taken from Ref. 44 and from unpublished results

verapamil. In parallel, verapamil also attenuated or even abolished the inhibitory effect of TPA on renin release. It is therefore not clear from our study whether TPA inhibits renin release by the phosphorylation of as yet unknown proteins via PKC activation or by enhancing the transmembrane calcium influx either dependent or independent of PKC activation.

Depite the uncertainty about the way by which TPA or protein kinase $\mathrm{C}$ inhibit renin release it can be inferred that activation of the protein kinase $\mathrm{C}$ does not stimulate the secretory process in the renal juxtaglomerular cells as it is typical for other secretory cells. Also in this regard the secretory mechanism in the juxtaglomerular cells seems to differ significantly from that of normal secretory cells.

\section{Role of Cyclic AMP for the Intracellular Control of Renin Release}

Activation of the adenylate cyclase is known as an important signal for the regulation of secretion in different types of secretory cells. In contrast to calcium the effect of CAMP on the secretion process is not uniform. As reviewed by Rassmussen and Barrett [64] cAMP can either enhance the secretory response (e.g. in pancreatic cells) or even decrease the secretory response (e.g. in platelets). The mechanism by which cAMP affects secretion in these cells has not been elucidated in detail but it seems likely that cAMP exerts its effect by the activation of cAMP dependent protein kinases [64]. Moreover there is growing evidence that
cAMP affects the secretion process by interfering with calcium and PKC activity [64].

With respect to the response to CAMP, the juxtaglomerular cells seem to behave like pancreatic or adrenal cells. In detail, there is broad evidence that substances activating the adenylate cyclase on the one hand, like $\beta$-catecholamines [26, 39], prostaglandins $[34,35,82,83]$, glucagone $[75,78]$, parathyroid hormone $[63,67]$ and on the other hand dibutyryl-cAMP $[2,52]$ all stimulate renin release. Furthermore, inhibition of cAMP phosphodiesterase also leads to a stimulation of renin release $[60,80]$. These findings were obtained using perfused kidneys, incubated kidney slices, incubated renal glomeruli and isolated juxtaglomerular cells. Using isolated juxtaglomerular cells we could also show that activators of the adenylate cyclase like isoproterenol, prostacyclin or forskolin enhanced the cellular content of cAMP within the juxtaglomerular cells and stimulated renin release [44].

The question therefore arises by which mechanism cAMP stimulates renin release. And in particular it has to be discussed whether or not cAMP influences renin release by a direct effect or by a decrease of the intracellular calcium concentration. In isolated juxtaglomerular cells we obtained evidence that the rate of renin release was correlated to the intracellular level of cAMP in presence of activators of the adenylate cyclase (Fig. 3). On the other hand an increase in the level of cAMP turned out not to be a prerequisite for the stimulation of renin release. In presence of the calcium channel blocker verapamil and the calmodulin an- 
tagonist trifluoperazine we observed an increase in the rate of renin release between $200-500 \%$ of control, a figure that is well comparable to the effect of isoproterenol or prostacyclin (Fig. 3). Verapamil and trifluoperazine, however, had no effect on the cellular cAMP level. Agents known to inhibit renin release such as angiotensin II on the other hand also failed to influence the cAMP level. We may conclude from these findings that cAMP is not the dominant regulator of renin release from juxtaglomerular cells.

It is evident therefore to discuss whether or not cAMP could stimulate renin release by affecting the intracellular concentration of calcium, in special by lowering this parameter. There are three pieces of experimental evidence to indicate that cAMP could stimulate renin release by lowering the intracellular concentration of calcium in juxtaglomerular cells. First, in experiments with isolated juxtaglomerular cells we have found that activators of the adenylate cyclase decrease the calcium permeability of the plasma membrane [44]. Second, it has been shown that the stimulatory effect of cAMP can be attenuated or even be abolished by increasing the intracellular concentration of calcium [19, 57, 77]. Third, it has been found for a variety of cells that cAMP is capable of stimulating $\mathrm{Ca}$-ATPases as well as the sodium-calcium exchange mechanism $[62,76]$. Both processes lead to a fall in the intracellular concentration of calcium. Taken together, there are arguments suggesting that cAMP and activators of the adenylate cyclase could stimulate renin release by lowering the intracellular calcium concentration. In this view cAMP would apparently influence the secretory process in juxtaglomerular cells in the same way as in other secretory cells. But the detailed mechanism by which cAMP acts on juxtaglomerular cells seems to be different from that of other secretory glands.

\section{Role of Cyclic GMP for the Intracellular Control of Renin Release}

The role of cGMP in the secretory process in general is only poorly understood. There are observations that stimulation of secretion from several cell types is accompanied by rises in intracellular cGMP levels [53]. The exact role of cGMP, however, in the secretory process is not known. Also, only very little information exists about the possible role of cGMP for the control of renin release from juxtaglomerular cells. Recently, a hormone has been discovered that is believed to act on its target cells by increasing the intracellular level of
cGMP. This hormone is the atrial natriuretic peptide [5] and besides its natriuretic effect this hormone has also been found to inhibit renal renin release $[9,32,50]$. Since it was not clear whether atrial natriuretic peptide exerted its effect by a direct action on juxtaglomerular cells or indirectly by activating the macula densa receptor, studies were performed in which the effect of atrial natriuretic peptide on renin release from renal cortical slices [55] and from isolated juxtaglomerular cells [46] was investigated. Both studies revealed that atrial natriuretic peptide led to a dose-dependent inhibition of renin release from these preparations. Atrial natriuretic peptide also caused an enhanced release of cGMP from the perfused kidney and a decreased release of cAMP in the kidney [55]. Since it is known that atrial natriuretic peptide is capable of stimulating guanylate cyclase in the kidney [74] and simultaneously inhibiting adenylate cyclase in the kidney [3], the question arose whether the inhibitory effect of atrial natriuretic peptide on renin relase was due to the rise in cGMP or to the decrease in cAMP. Using isolated juxtaglomerular cells we obtained clear evidence that the inhibition of renin release from the cells in presence of atrial natriuretic peptide was correlated with the level of cGMP and not with the level of cAMP [47]. Moreover we found that renin release from the isolated juxtaglomerular cells was inversely related to the cellular level of cGMP (Fig. 4). From these findings it can be inferred that atrial natriuretic peptide inhibits renin release by rising the intracellular level of cGMP. This indicates that cGMP is an inhibitory signal in the control of renin release in juxtaglomerular cells.

As with cAMP again the question arises whether cGMP has a direct effect in the regulation of renin release or whether it acts indirectly by increasing the intracellular calcium concentration. We therefore measured the transmembrane calcium influx rate and the quin-2 signal of isolated juxtaglomerular cells in presence of atrial natriuretic peptide. However, we failed to detect any influence of atrial natriuretic peptide on either the transmembrane calcium influx or on the intracellular calcium concentration as monitored by the quin-2 signal [46]. It is likely therefore that the inhibitory role of CGMP on renal renin release does not involve an increase in the cytosolic calcium concentration.

Recently we have found that adenosine, which is known to inhibit renin release from whole kidneys and renal cortical slices, also inhibited renin release from isolated juxtaglomerular cells up to a concentration of $10^{-6} \mathrm{M}$. At these concentra- 


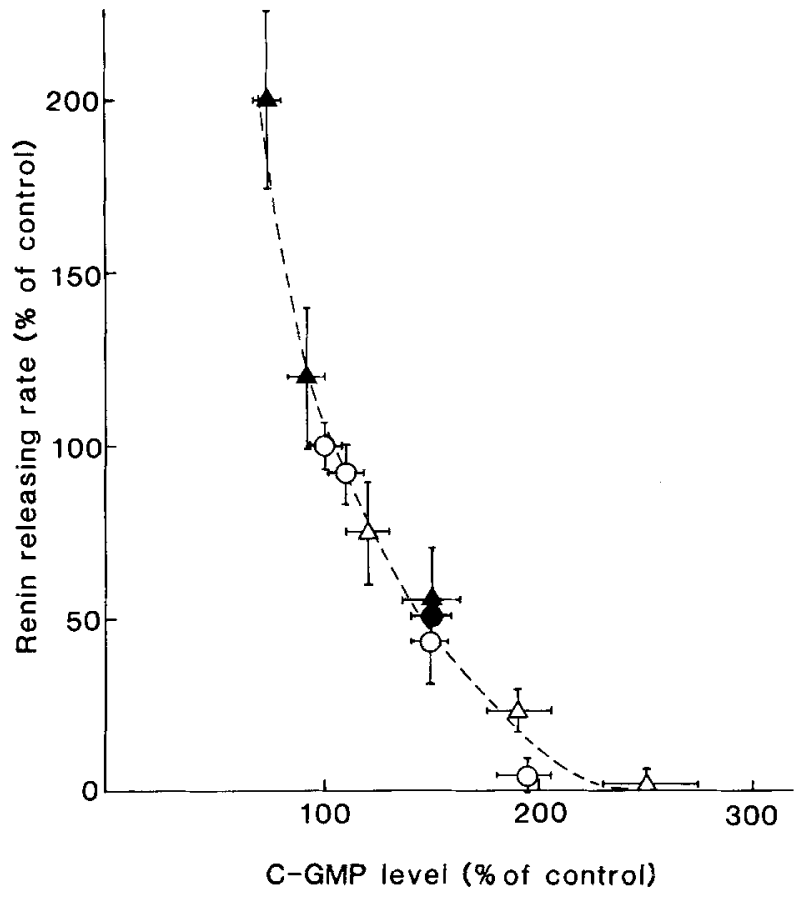

Fig. 4. Correlation between the intracellular level of cGMP and renin release from isolated juxtaglomerular cells. Data are taken from Ref. 46

tions of adenosine no significant alterations of transmembrane calcium influx and of the quin-2 signal could be detected. However, at these concentrations significant rises in intracellular cGMP were observed, whilst the concentration of cAMP was totally unchanged. This observation could be taken as a further support for the idea that cGMP could be a direct inhibitor of renin release in the renal juxtaglomerular cells.
It should be noted in this context that we found in isolated juxtaglomerular cells that the inhibitory effect of atrial natriuretic peptide on renin release was markedly attenuated in the presence of the calcium channel blocker verapamil [47]. Since we have found that verapamil also decreases the basal calcium influx into the cells [44, 45], one could speculate from all of these findings that cGMP requires a normal calcium concentration to exert its maximal inhibitory effect on renin release. In summary, experimental evidence indicates that cGMP is an inhibitory signal for renin release from juxtaglomerular cells without affecting intracellular calcium concentration.

\section{Conclusions}

The present knowledge about the intracellular control of renin release is summarized in Fig. 5.

The detailed mechanisms by which calcium, cGMP, cAMP and protein kinase $\mathrm{C}$ influence renin secretion from juxtaglomerular cells is not known so far. In general, calcium, and cyclic nucleotides are thought to exert their metabolic effects by the activation of specific protein kinases. Application of this concept on juxtaglomerular cells leads to the following model: Activation of a calcium dependent protein kinase, of cGMP dependent protein kinase and of the phospholipid dependent protein kinase $\mathrm{C}$ inhibit renin release. If one accepts that the rate of renin release is correlated to the rate of membrane fusions between renin granules and the plasma membrane [73], then it could be speculated that these membrane fusions are inhibited by the activation of the protein kinases mentioned above.

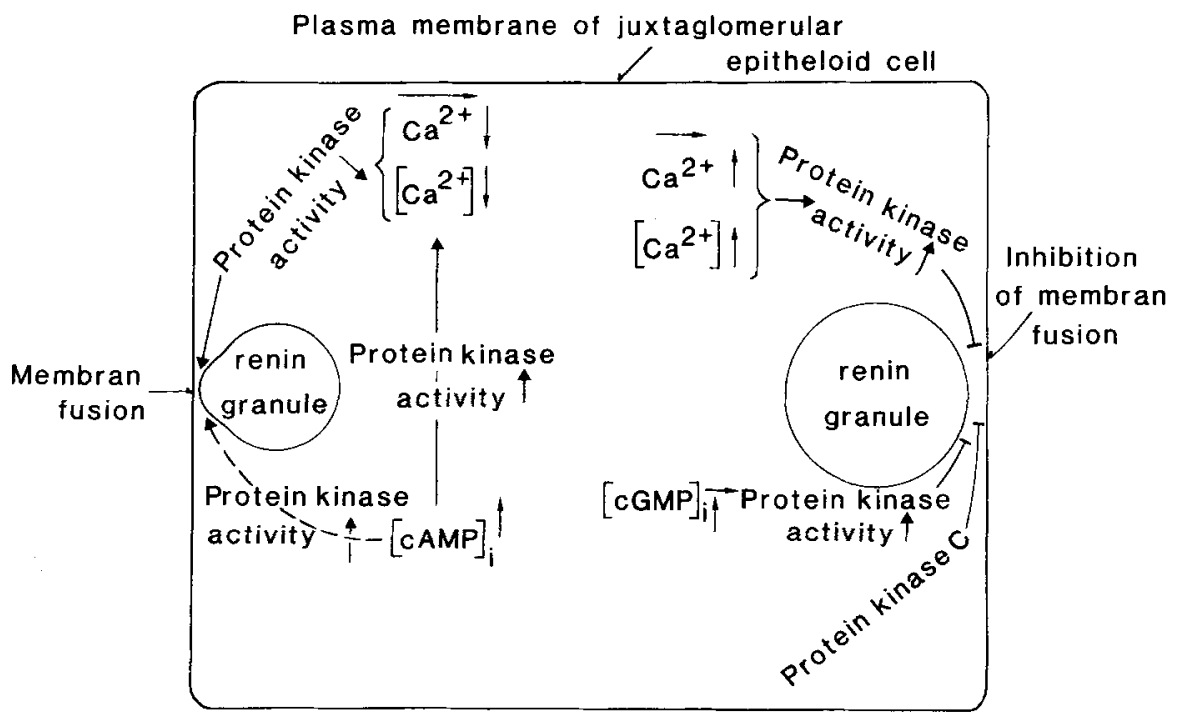

Fig. 5. Model summarizing the present knowledge about the effects of calcium, protein kinase $\mathrm{C}$ and cyclic nucleotides on the intracellular control of renin release from renal juxtaglomerular cells.

$\begin{array}{ll}\downarrow & \begin{array}{l}\text { decrease } \\ \text { increase } \\ \text { transmembrane calcium }\end{array} \\ {\left[\mathrm{Ca}^{2+}\right.} & \begin{array}{l}\text { influx } \\ \text { cytosolic free calcium } \\ \text { concentration } \\ \text { concentration of }\end{array} \\ {[\mathrm{CAMP}]_{i}} & \begin{array}{l}\text { intracellular cAMP } \\ \text { concentration of } \\ \text { intracellular cGMP }\end{array}\end{array}$


Activation of a cAMP dependent protein kinase on the other hand will stimulate renin release. This could mean that the membrane fusion between the renin granule and the plasma membrane is faciliated by the action of a cAMP dependent protein kinase. Another explanation could be that the activation of a cAMP dependent protein kinase results in a fall in the intracellular concentration of calcium which in turn would lead to an inactivation of the calcium dependent protein kinase. Inhibition of the inhibitory function of the calcium dependent protein kinase for renin release would then lead to a stimulation of renin secretion.

To test the correctness of this model remains a task for the future. Isolated juxtaglomerular cells could be a valuable experimental tool for this problem.

Acknowledgements: I wish to thank Prof. Christian Bauer for helpful discussions.

\section{References}

1. Abe Y, Yukimura T, Iwao H, Mori N, Okahara T, Yamamoto $\mathrm{K}$ (1983) Effects of EDTA and verapamil on renin release in dogs. Jpn J Pharmacol 33:627-633

2. Allison DJ, Tanigawa H, Assaykeen TA (1972) The effects of cyclic nucleotides on plasma renin activity and renal function in dogs. In: Assaykeen TA (ed) Control of renin secretion. Plenum Press, New York, pp 33-47

3. Anand-Srivasta MB, Franks DJ, Cantin M, Genest J (1984) Atrial natriuretic factor inhibits adenylate cyclase activity. Biochem Biophys Res Commun 121:855-862

4. Baker PF (1976) The regulation of intracellular calcium. In: Duncan CJ (ed) Calcium in biological systems. Cambridge, Cambridge Univ. Press, pp 485

5. Ballermann BJ, Brenner BB (1985) Biologically active atrial peptides. J Clin Invest $76: 2041-2048$

6. Barajas L (1979) Anatomy of the juxtaglomerular apparatus. Am J Physiol 237:F333-F343

7. Berridge MJ (1984) Inositol trisphosphate and diacylglycerol as second messengers. Biochem J 220:345-360

8. Blaustein MP (1974) The interrelationship between sodium and calcium fluxes across cell membrane. Rev Physiol Biochem Exp Pharmacol 70:33-80

9. Burnett JC, Granijer JP, Opengoth TS (1984) Effects of synthetic atrial natriuretic factor on renal function and renin release. Am J Physiol 247: F863-F867

10. Capponi AM, Valloton MB (1976) Renin release by rat kidney slices incubated in vitro. Role of sodium and $\alpha$ and $\beta$-adrenergic receptors and effect of vincristine. Circ Res 39:200-203

11. Castagna M, Takai Y, Kaibuchi K, Sano K, Kikkawa U, Nishizuka Y (1982) Direct activation of calcium activated phospholipid dependent protein kinase by tumor promoting phorbol esters. J Biol Chem 251:7847-7851

12. Charesi R, Blackmore PF, Berthon B, Exton JH (1983) Changes in cytosolic free $\mathrm{Ca}^{2+}$ in hepatocytes following $\alpha-1$ adrenergic stimulation. J Biol Chem 258:8769-8773

13. Cheng WY (1982) Calmodulin: an overview. Fed Proc $41: 2253-2257$

14. Churchill P (1979) Possible mechanism of the inhibitory effect of ouabain on renin secretion from rat renal cortical slices. J Physiol (London) 294:123-134

15. Churchill PC (1980) Effect of D-600 on inhibition of in vitro renin release in the rat by high extracellular potassium and angiotensin II. J Physiol (London) 304:449-458

16. Churchill PC (1981) Calcium dependency of the inhibitory effect of antidiuretic hormone on in vitro renin secretion in rats. J Physiol (London) 315:21-30

17. Churchill PC (1985) Second messengers in renin secretion. Am J Physiol 249:F175-F184

18. Churchill PC, Churchill MC (1980) Vanadate inhibits renin secretion from rat kidney slices. J Pharmacol Exp Ther 213:144-149

19. Churchill PC, Churchill MC (1982) Isoproterenol stimulated renin secretion in the rat: second messenger roles of $\mathrm{Ca}$ and cyclic AMP. Life Sci 30:1313-1319

20. Churchill PC, Churchill MC (1982) Ca-dependence of the inhibitory effect of $\mathrm{K}$-depolarization on renin secretion from rat kidney slices. Arch Int Pharmacodyn Ther 258:300-312

21. Churchill MC, Churchill PC, McDonald FD (1983) Comparison of the effects of rubidium and potassium on renin secretion from rat kidney slices. Endocrinology 112:777-781

22. Churchill PC, Churchill MC (1983) Effects of trifluoperazine on renin secretion of rat kidney slices. J Pharmacol Exp Ther 224:68-72

23. Churchill PC, Churchill MC (1984) 12-O-Tetradecanoylphorbol 13-Acetate (TPA) inhibits renin secretion of rat renal cortical slices. J Hypertens 2 (suppl 1):25-28

24. Churchill PC, McDonald FD, Churchill MC (1981) Effect of diltiazem a calcium antagonist on renin secretion from rat kidney slices. Life Sci 29:383-389

25. Cruz-Soto M, Benabe JE, Lopez-Novoa JM, Martinez-Maldonado $\mathrm{M}(1984) \mathrm{Na}^{+}-\mathrm{K}^{+}$-ATPase inhibitors and renin release: relationship to calcium. Am J Physiol 247: F650-F655

26. Davies JO, Freeman RH (1976) Mechanisms regulating renin release. Physiol Rev 56:1-56

27. Flynn M, Onomakpone N, Peart WS (1977) The effects of ionophores (A 23187 and $\mathrm{RO}_{2}-2985$ ) on renin secretion and renal vasoconstriction. Proc $R$ Soc London Ser B 199:199-212

28. Fray JCS (1977) Stimulation of renin release in perfused kidney by low calcium and high magnesium. Am J Physiol 232:F377-F382

29. Fray JCS (1980) Mechanism by which renin secretion from rat kidneys is stimulated by isoprenaline and inhibited by high perfusion pressure. J Physiol (London) 308:1-13

30. Fray JCS, Park CS (1979) Influence of potassium, sodium, perfusion pressure and isoprenaline on renin release induced by calcium deprivation. J Physiol (London) 292:363-372

31. Fray JCS, Lush DJ, Share D, Valentine AND (1983) Possible role of calmodulin in renin secretion from isolated rat kidneys and renal cells: studies with trifluoperazine. J Physiol (London) 343:447-454

32. Garcia R, Thibault G, Gutkowska J, Hamet P, Cantin M, Genest J (1985) Effect of chronic infusion of synthetic atrial natriuretic factor (ANF 8-33) in conscious two-kidney, oneclip hypertensive rats. Proc Soc Exptl Med Biol 178:155-159

33. Garrison JC (1983) Role of $\mathrm{Ca}^{2+}$ - dependent protein kinases in the response of hepatocytes to $\alpha-1$ agonist, angiotensin II and suppressants. In: Harris RA, Cornell NW (eds) Isolation, Characterization and Use of Hepatocytes. Elsevier, Amsterdam, pp 551-559

34. Gerber JG, Branch RA, Nies AS, Gerkens JF, Shand DG, Hollifield J, Oates JA (1978) Prostaglandins and renin relea- 
se II. Assessment of renin secretion following infusions of $P G I_{2}, E_{2}$, and $D_{2}$ into the renal artery of anesthetized dogs. Prostaglandins 15:81-88

35. Hackenthal E, Schwertschlag U, Seyberter HW (1980) Prostaglandins and renin release. Studies in the isolated perfused kidney; In: Mahoney and Stokes (eds) Hormones and the kidney. Prog Biochem Pharmacol 17:98-107

36. Hackenthal E, Schwertschlag U, Taugner R (1983) Cellular mechanisms of renin release. Hypertension A5/7 \& 8:975993

37. Harada E, Rubin RP (1978) Stimulation of renin secretion and calcium efflux from the isolated perfused cat kidney by norepinephrine after calcium deprivation. J Physiol (London) 247:367-379

38. Kawamura M, Inagami $T$ (1983) Calmodulin antagonists stimulate renin release from isolated rat glomeruli. Endocrinology 112:1857-1859

39. Keeton TK, Campbell WB (1981) The pharmacologic alteration of renin release. Pharmacol Rev 31:81-227

40. Kisch ES, Dluhy RG, Williams GH (1976) Regulation of renin release by calcium and ammonium ions in normal man. J Clin Endocrinol Metab 43:1343-1350

41. Kojima J, Kojima K, Kreutter D, Rasmussen H (1984) The temporal integration of the aldosterone secretory response to angiotensin II occurs via two intracellular pathways. J Biol Chem 259:14448-14457

42. Kojima J, Kojima K, Rasmussen H (1985) Role of calcium fluxes in the sustained phase of angiotensin II - mediated aldosterone secretion from adrenal glomerulosa cells. J Biol Chem 260:9177-9184

43. Kotchen TA, Maull KJ, Luke RG (1977) Effect of calcium gluconate infusion on renin in the dog. $J$ Lab Clin Med 89:181-189

44. Kurtz A, Pfeilschifter J, Bauer C (1984) Is renin secretion governed by the calcium permeability of the juxtaglomerular cell membrane? Biochem Biophys Res Commun $124: 359-366$

45. Kurtz A, Pfeilschifter J, Hutter A, Bührle CP, Nobiling R, Taugner R, Hackenthal E, Bauer C (1986) Role of protein kinase $\mathrm{C}$ in vasoconstrictor caused inhibition of renin release. Am J Physiol 250:563-571

46. Kurtz A, Della-Bruna R, Pfeilschifter J, Taugner R, Bauer C (1986) Atrial natriuretic peptide inhibits renin release from isolated renal juxtaglomerular cells by a c-GMP mediated process. Proc Natl Acad Sci USA (in press)

47. Kurtz A, Della-Bruna R, Pfeilschifter J, Bauer C (1986) Effect of atrial natriuretic peptide on rat renal juxtaglomerular cells. J Hypertens (in press)

48. Lopez-Novoa JM, Garcia JC, Cruz-Soto MA, Benabe JE, Martinez-Maldenado M (1982) Effect of sodium orthovanadate on renal renin secretion in vivo. I Pharmacol Exp Ther 222:447-451

49. Lyons HJ, Churchill PC (1974) The influence of ouabain on in vitro renin secretion. Proc Soc Exp Biol Med $145: 1148-1150$

50. Maack T, Marion DN, Camargo MJF, Kleinert HD, Laragh JH, Vaughan ED, Atlas SA (1985) Effects of auriculin (atrial natriuretic factor) on blood pressure, renal function and the renin-aldosterone system in dogs. Am $\mathrm{J}$ Med $77: 1069-1075$

51. Matsumura Y, Sasaki Y, Shinyama H, Morimoto S (1985) The calcium channel agonist, Bay $\mathrm{K} 8644$, inhibits renin release from rat kidney cortical slices. Europ J Pharmacol 117:369-372

52. Michelakis AM, Caudle J, Liddle GW (1969) In vitro stimulation of renin production by epinephrine, norepinephrine and cyclic AMP. Proc Soc Exp Biol Med 130:748-753
53. Nishizuka Y (1983) Calcium, phospholipid turnover and transmembrane signalling. Phil Trans R Soc Lond B 302:101-112

54. Nishizuka Y (1984) Turnover of inositol phospholipids and signal transduction. Science 225:1365-1369

55. Obana K, Naruse M. Naruse K, Sakurai H, Demura H, Inagami T, Shizume K (1985) Synthetic atrial natriuretic factor inhibits in vitro and in vivo renin secretion in rats. Endocrinology 117:1282-1285

56. O'Neal SG, Rhoads DB, Rador E (1979) Vanadate inhibition of sarcoplasmic reticulum $\mathrm{Ca}^{2+}$-ATPases and other ATPases. Biochem Biophys Res Commun 89:845-850

57. Opengorth TJ, Zehr JE (1983) Role of calcium in the interaction of alpha and beta adrenoreceptor-mediated renin release in isolated constant pressure perfused rabbit kidneys. J Pharmacol Exp Ther 227:144-149

58. Park CS, Malvin RL (1978) Calcium in the control of renin release. Am J Physiol 235: F22-F25

59. Park CS, Han DS, Fray JCS (1981) Calcium in the control of renin secretion: $\mathrm{Ca}^{2+}$ influx as an inhibitory signal. Am J Physiol 240:F70-F47

60. Peart WS, Quesada T, Tengi I (1975) The effects of adenosine $3^{\prime}, 5^{\prime}$ monophosphate and guanosine $3^{\prime}, 5^{\prime}$ monophosphate and theophylline on renin secretion in the isolated perfused kidney of the rat. Brit $J$ Pharmacol 54:55-60

61. Pfeilschifter J, Kurtz A, Bauer C (1985) Inhibition of renin release by platelet activating factor (acetylglyceryl ether phosphorycholine) in cultured rat juxtaglomerular cells. Biochem Biophys Res Commun 127:903-910

62. Phillis JW, Wu PH (1981) Catecholamines and the sodium pump in excitable cells. Prog Neurobiol Oxford 17:141-184

63. Powell HR, McCredie DA, Rotenberg E (1978) Renin release by thyroid hormone in the dog. Endocrinology 103:985-989

64. Rasmussen H, Barrett PQ (1984) Calcium messenger system. An integrated review. Physiol Rev 64:938-984

65. Schwertschlag U, Hackenthal E (1983) Short communication: trifluoperazine antagonizes inhibition of renin release by angiotensin II. Clin Exp Pharmacol Physiol 10:605-608

66. Seeman P (1972) The membrane actions of anesthetics and tranquilizers. Pharmacol Rev 24:583-655

67. Smith JM, Moun DR, Vander AJ (1979) Effect of parathyroid hormone on plasma renin activity and sodium excretion. Am J Physiol 236:F311-F319

68. Snowdowne KW, Borle AB (1984) Changes in cytosolic ionized calcium induced by activators of secretion in $\mathrm{GH}_{3}$ cells. Am J Physiol 246:E198-E201

69. Streb H, Irvine RF, Berridge MJ, Schulz I (1983) Release of $\mathrm{Ca}^{2+}$ from a nonmitochondrial store in pancreatic acinar cells by inositol 1, 4, 5-trisphosphate. Nature 306:67-70

70. Studer RK, Snowdowne KW, Borle AB (1984) Regulation of hepatic glycogenolysis by glucagone in male and female rats. J Biol Chem 259:3596-3604

71. Takai Y, Kishimoto A, Kawahara Y, Minakuchi K, Sano $\mathrm{K}$, Kikkawa U, Mori T, Yu B, Kaibuchi K, Nishizuka $Y$ (1981) Calcium and phosphatidylinositol turnover as signalling for transmembrane control of protein phosphorylation. Adv Cyclic Nucleotide Res 14:301-313

72. Takai Y, Kikkawa U, Kaibuchi U, Nishizuka Y (1984) Membrane phospholipid metabolism and signal transduction for protein phosphorylation. Adv Cyclic Nucleotide Res 18:119-158

73. Taugner R, Bührle CP, Hackenthal E, Mannek E, Nobiling $R$ (1984) Morphology of the juxtaglomerular apparatus and secretory mechanisms. In: Berlyne GM, Giovannetti S (eds) Contributions to Nephrology, Vol. 43. S Karger, Basel, pp 76-101 
74. Tremblay J, Gerzer R, Vinay P, Pang SC, Beliveau R, Hamet $\mathbf{P}$ (1985) The increase of CGMP by atrial natriuretic factor correlates with the distribution of particulate guanylate cyclase. FEBS lett 181:17-22

75. Ueda J, Nakanishi H, Abe Y (1978) Effect of glucagon on renin secretion in the dog. Eur J Pharmacol 52:85-92

76. van Breemen C, Aaronson P, Loutzenhiser R (1979) Sodium calcium interactions in mammalian smooth muscle. Pharmacol Rev 30:167-208

77. Vandongen $R$ (1975) Inhibition of renin secretion in the isolated rat kidney by antidiuretic hormone. Clin Sci Mol Med 49:73-76

78. Vandongen R, Peart WS, Boyd GW (1973) Adrenergic stimulation of renin secretion in the isolated perfused rat kidney. Circ Res 32:290-296

79. Vandongen R, Peart WS (1974) Calcium dependence of the inhibitory effect of angiotensin on renin secretion in the isolated perfused kidney of the rat. Br J Pharmacol $50: 25-129$
80. Viskoper RJ, Maxwell MH, Lupu AN, Rosenfield S (1977) Renin stimulation by isoproterenol and theophylline in the isolated perfused kidney. Am J Physiol 232:F248-F253

81. Watkins BE, Davies JO, Lohmeier TE, Freeman RH (1976) Intrarenal site of action of calcium on renin secretion in dogs. Circ Res $39: 847-853$

82. Weber PC, Larssen C, Angaard E, Hamberg M, Corey EJ, Nicolaou KC, Samuelsson B (1976) Stimulation of renin release from rabbit renal cortex by arachidonic acid and prostaglandin endoperoxides. Circ Res 39:868-874

83. Werning C, Vetter W, Weidmann $\mathrm{P}$, Schwiekert HU, Stiel $D$, Siegenthaler W (1971) Effect of prostaglandin $E_{1}$ on renin in the dog. Am J Physiol 220:852-856

Dr. Armin Kurtz

Physiologisches Institut der

Universität Zürich

Winterthurerstr. 190

CH-8057 Zürich/Schweiz 